\title{
The Effects of Consumer Ethnocentrism and Consumer Animosity on the Willingness to Buy with the Mediating Role of Products Judgments: Children's Food Case
}

\author{
Nguyen Ngoc Quang, Truong DinhChien, Nguyen Hoai Long* \\ Marketing Faculty, National Economics University, Vietnam
}

Copyright $(2017$ by authors, all rights reserved. Authors agree that this article remains permanently open access under the terms of the Creative Commons Attribution License 4.0 International License

\begin{abstract}
With the growth of international business and travel, Vietnamese consumers are increasingly confronted with foreign products and services especially children's foods. However, some negative attitudes towards foreign products can arise from several factors such as historic or ongoing political, military, economic, or diplomatic events. Thus, both consumer ethnocentrism and consumer animosity have become important constructs in marketing. The purpose of this study is to investigate whether consumer ethnocentrism and consumer animosity affect Willingness to buy towards Chinese Children's foods and whether this impact is mediated by products judgments. Structural equation modeling was used to analyze the data collected from 846 personal interviews carried out in three Vietnamese cities (Hanoi, Danang, and Ho Chi Minh). The findings of the research indicate that consumer ethnocentrism increases consumer animosity. The present study also denotes that both consumer ethnocentrism and animosity have a negative impact on Willingness to buy toward Chinese children's foods. Product judgments may not be an important mediating factor between consumers' animosity - Willingness to buy and between consumer ethnocentrism - Willingness to buy toward Chinese Children's foods.
\end{abstract}

Keywords Consumer Ethnocentrism, Consumer Animosity, Product Judgments Willingness to Buys, Foreign Products, Children's Foods

\section{Introduction}

The globalization and liberalization in trading enable goods spread and become available around the world market. Consumer always has to make decision on choosing between domestic products or foreign products. As the result, companies have to take great effort to assist customer make their purchase decision on their products. Governments try to encourage people over the world to buy products made in their countries. Thus, it is important to know the customer's willingness to buy is influenced by what and how. With the subject "The Effects of Consumer Ethnocentrism and Consumer Animosity on the Willingness to buy with The Mediating Role of Products Judgments: Children's foods case", this research aims to answer the question "how Vietnamese customer's willingness to buy is effected by their ethnocentrism and animosity".

It was proved by researchers that there are relationships between customer's willingness to buy foreign product and customer's ethnocentrism and animosity. Customers following ethnocentrism tend to prefer domestic products to foreign products. Customers also tend to reject products that they have animosity to the country of origin. The impacts of customer's ethnocentrism and animosity to customer's willingness to buy foreign product are mediated by customer's products judgment.

With the trio relationship between consumer ethnocentrism - consumer animosity - products judgment as the focal construct, this study seeks to accomplish the following two major objectives: (a) to examine the effect of consumer ethnocentrism and consumer animosity on buying attitude towards Chinese products; and (b) to examine whether children's foods products judgment mediates the relationships between consumer animosity and willingness to buy as well as between ethnocentrism and consumers' willingness to buy. Because of Vietnam is a developing country with a high level of foreign trade especially with China. This research will examine the extension to which the proposed ethnocentrism model is affected by the above-mentioned variables, and this will be of great relevance for international marketers.

\section{Buying Behavior towards Foreign Products}

With the globalization, consumer can choose goods made 
in any country in the world, but they always have to make decision to buy domestic or foreign products. With this decision, customers have to set their standards of products judgment. Researchers have tried to point out the factors that influence customer's product judgment. "Consumer preferences for products of a specific origin can be a consequence of diverse reasons: products dependency, country-of-origin image, similarities between countries, a country's level of development and/or consumers' beliefs, stereotypes and experiences" [7]. The customer's trust and perceptions about a certain country influence their evaluations at the time of purchasing [13]. In general, many papers showed that country of origin impact to customer's products judgment. "Products origin and its effects are associated with different emotive and normative variables taken from others disciplines such as psychology and sociology where the concepts of ethnocentrism and animosity have their roots" [4]. Thus, ethnocentrism and animosity have an impact in customers' product judgment and willingness to buy foreign products.

\section{Variables, Hypotheses and Model}

It was pointed out that willingness to buy of foreign-made products and domestic products are impacted by ethnocentrism and animosity [18].

\subsection{Consumer Ethnocentrism}

Ethnocentrism is a psychological concept that was created by William G. Sumner in 1906. Ethnocentrism is judging another culture solely by the values and standards of one's own culture. In general, ethnocentric individuals tend to think that their group is superior to others.

Consumer ethnocentrism is a particular concept that is derived from the concept of ethnocentrism. LeVine \& Campbell defined consumer ethnocentrism as "the symbols and values of one's own ethnic or national group become objects of pride and attachment, whereas symbols of other groups may become objects of contempt" [19]. Having applied ethnocentrism concept to marketing and consumer behavior, Shimp \& Sharma formulated consumer ethnocentric tendency (CET) as a "unique economic form of ethnocentrism that captures the beliefs held by consumers about the appropriateness and, indeed, morality of purchasing foreign-made products" [26]. CET refers to a consumer's tendency to prefer his or her own country's products (i.e., in-group) to foreign products (i.e., out-group) for economic or patriotic reasons. Several research papers show that people with high CET have a trend to buy less foreign products which are unnecessary products and imports possibly threatening their personal or national wellbeing $[20,25,26]$.

Consumer ethnocentrism is simply explained that it is ethnocentric view held by consumers in one country, the in-group, towards products from another country, the out-group [26]. Ethnocentric attitude is mentioned in the research of Sharma et al. [25]. This term refers to an individual tendency to believe that it is disloyal to the country to buy foreign products, because it could cause a negative effect on the domestic economy [26].

It was found that ethnocentric consumers tend to avoid buying products from any foreign country [2, 10, 25, 26, 28]. Therefore, evaluations and buying intentions of such consumers are influenced by consumer ethnocentrism. This conclusion has pointed out in some particular research for example ethnocentrism of American consumers influence to buying intentions to buy foreign-made automobiles [26] or studies with Portuguese and Korean consumers showed that ethnocentrism increases the rejection of foreign products and enhances the purchase intentions towards domestic products $[10,28]$. Studies showed that consumers prefer to buy domestic products rather than foreign imports as a consequence of their ethnocentrism.

Thus, consumer ethnocentrism has a negative impact into customer willingness to buy foreign products.

H1: Consumer ethnocentrism has a significant and negative impact on Willingness to buy.

\subsection{Consumer Animosity}

Animosity was defined as "an attitude includes both cognitive beliefs and affective feelings". Animosity was consider as "a pure affective construct" [3, 5]. In consumer behavior and marketing fields, Animosity term was first introduced by Klein et al [18]. Therefore, consumer animosity was defined as "remnants of antipathy related to previous or ongoing military, political, or economic events that affect consumers' willingness to purchase foreign products". Consumer animosity refers to attitudes of the members of one nation towards the products of another nation. It's showed that there are strong negative emotions toward buying products from a disliked nation or group [24].

Based on source (situational vs. stable) and locus of manifestation (personal vs. national), it was proposed four types of animosity: national stable animosity, personal stable animosity, national situational animosity, and personal situational animosity $[2,14]$. It's proposed that there was two cause of animosity, it's was war animosity and economic animosity. War animosity is caused by war between conflicting nations, it was negatively related to purchase intention and positively related to consumer ethnocentrism. Economic animosity is caused by economic conflict; it was negatively related to purchase intention and positively related to consumer ethnocentrism [22]. This classification is used popularly in the studies related to animosity and its impact to consumer behavior. Both war animosity and economic animosity impact on willingness to buy.

It is showed that consumer animosity towards one specific foreign country can adversely impact on the consumption of 
products from that country, both consumer judgments on product quality and its value or characteristics $[16,18]$. If consumers have feelings of animosity to a nation (deriving from war economic issues) their willingness to buy products made in that country will be reduced or may be null. And, animosity could be an antecedent to consumers rejecting foreign products made in countries against which their animosity. For example, with the animosity with Japan, Chinese has low willingness to buy Japanese product as a consequence of past economic and armed conflicts between the two nations [18].

Thus, consumer animosity impacts into consumer willingness to buy foreign product. The influent of consumer animosity on consumer willingness to buy foreign product is mediated by product judgment of customer.

H2A: Consumer war animosity has a significant and negative impact on Willingness to buy.

H2B: Consumer economic animosity has a significant and negative impact on Willingness to buy.

\subsection{The Relationships between Ethnocentrism, Animosity}

Customer ethnocentrism and Customer animosity are different concepts [17, 18]. But both Customer ethnocentrism and Customer animosity are influence consumer behavior. Consumer animosity and consumer ethnocentrism are related to certain attitudes towards foreign products which may stem from economic, military, and political events $[17,18]$. Customer animosity impacts to customer behavior when buying products that import from a specific nation. Customer ethnocentrism influents customer behavior and tends to make them reject all foreign products $[9,18,23]$. Consumer ethnocentrism relates to consumers' willingness to buy and products judgments. Consumer ethnocentrism is "concerned with consumers' attitudes towards all foreign countries and is associated with general convictions that it is unpatriotic or inappropriate to buy foreign products as this may negatively affect the domestic economy" $[17,28]$. So, customer ethnocentrism influences to customer animosity.

H3A: Consumer ethnocentrism positively influences to consumer war animosity.

H3B: Consumer ethnocentrism positively influences to consumer economic animosity.

\subsection{Foreign Product Judgment}

Thanks to the trade liberalization and globalization, customer always has information and consider carefully before buying domestic products or foreign products. Some studies in marketing and customer behavior field on foreign products judgment have carried out. Klein et al [18], Nijssen \& Douglas [22] have researched on relationship between consumer animosity and foreign products judgment. The relationship between consumer ethnocentrism and foreign product judgment has been researched by Hamin \& Elliot [12], Kaynak \& Kara (2002) [15]. These studies have pointed out that highly ethnocentric consumers will negatively evaluated foreign made products. It's indicated a positive relationship between consumer ethnocentrism and judgment of domestic products, and a negative association between consumer ethnocentrism and imported products judgment.

H4: Product judgments mediate the relationship between consumer ethnocentrism and Willingness to buy.

H5A: Product judgments mediate the relationship between consumer war animosity and Willingness to buy.

H5B: Product judgments mediate the relationship between consumer economic animosity and Willingness to buy.

\subsection{Willingness to Buy Foreign Products}

Customer behavior theory has pointed out that consumers usually hold prior buying intentions before their action. Customers tend to buy products that they put in the first priority of their evaluation. Product judgment help customer setting the priority of choices.

In fact, it's difficulty in observing the buying behavior so researchers have largely employed this buying intention as an antecedent of behavior because it simplifies the measurement of behavior although it is not perfect $[6,21,29]$. Hamin \& Elliot [12] have pointed that consumers in different countries give dissimilar priorities to the factors that affected their purchase intentions. Some other studies in specific situations also gave conclusion that "the stronger the consumer purchase intention, the greater the probability of the consumer buying the products being evaluated" [6].

In this research, buying intention refer to the willingness to buy foreign products. Based on the prediction that willingness to buy has close relationship with buying action, this research investigates on how customer ethnocentrism and customer animosity impact to products judgments and customer willingness to buy foreign products.

Figure 1 depicts the eight proposed hypotheses described above that will be empirically contrasted. The methodology and results are discussed in the following sections.

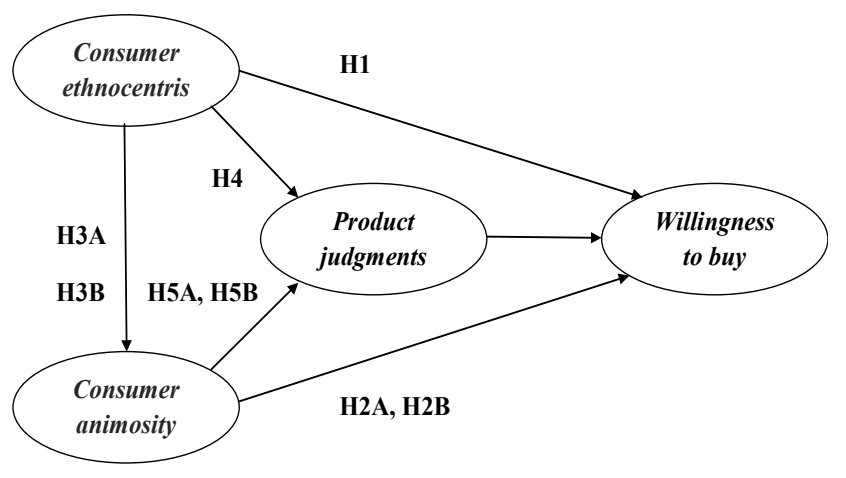

Figure 1. Proposed Model 


\section{Research Methodology}

\subsection{Foreign Products and Chinese Children's Foods Selection}

This research focuses on analyzing factors that influent Vietnamese consumers' Willingness to buys towards Chinese Children's foods. With this purpose, the sample, Chinese children's foods selection should allow us to test relationships between ethnocentrism, animosity, product judgments and Willingness to buy. Preferences for products from Vietnam or any one foreign country do not only depend on the specific characteristics and category of each product, but also on the specific country, context or patriotism.

The ethnic animosity between Vietnam and China is widely known. The adversarial relationship between the two peoples began more than one thousand years ago when Vietnam has got independence from China Empire. In the centuries that followed, a powerful China was able to gradually conquer the various Vietnam lands. While the modern independent Vietnam state came into existence in 1975 , following a long revolutionary war, numerous wars and islands disputes in the years that followed have not allowed the two nations to forget the past and build a peaceful future. Therefore, for various reasons, the Vietnam-China animosity and distrust still exist and are reflected in many parts of the everyday lives of the respective nations and may be influencing the purchasing decisions that the consumers of the two countries make.

Commercial ties between Vietnam and China have greatly improved in recent years following recent positive political developments. Based on National Statistical Service of Vietnam data in 2016, China is Vietnam's largest trade partner with total turnover over $\$ 50$ billion, up to 22 percent year-to-year. Bilateral trade turnover is expected to reach $\$ 60$ billion in 2017. During the period, imports from China accounted for $28 \%$ percent of Vietnam's total import value, while exports to China accounted for 10 percent of total export value. However, while this increase in trade has been very positive for the future relations between the two countries, it has mainly concentrated on industrial products and raw materials.

This study explores the attitudes of Vietnam consumers towards Chinese children's foods. Children's foods purchasing implies a high level of health sensibility and consumers spend more time and money looking for additional information to evaluate this product than they spend on purchasing other products. Consumers are more sensitive to country-of-origin when purchasing children's foods with a symbolic status, than for foods that are purchased for adults.

\subsection{Data Collection}

The data for this study were collected through "mall intercepts" in three different locations in May and June 2016 to investigate the feelings of a cross-section of the Vietnam public. Approximately 846 completed questionnaires were included in the data analysis of the study. The data were collected by randomly approaching Vietnamese children's foods buyer in three Vietnam cities. They were questioned in supermarket when buying foods for children. The target group is the household with children under 10 years old and living in Hanoi Capital in the North, Danang City in the Center and Ho Chi Minh City in the South.

The three different locations provided us with a fairly accurate representation of a wide spectrum of Vietnamese consumers. Hanoi in the North being the capital and the second largest city in Vietnam is the home to the most educated and most cosmopolitan consumers. Ho Chi Minh City in the South is the largest and the richest city in Vietnam. Danang City is selected because it represents center land of Vietnam.

The questionnaire was originally composed in English and then translated into Vietnamese. Another independent translator then back translated the Vietnamese version of the questionnaire into English to ensure its validity. The final Vietnamese version of the questionnaire was shown to a small number of Vietnamese consumers to ensure that it was easily understood by the average of Vietnamese consumers.

A survey was used to test the model and hypotheses. The socio-economic and demographic profile of the respondents of the sample is as follows: $13.4 \%$ male and $86.6 \%$ female. Their age groups are as follows: $6.3 \%$ under 26 years old, $48.8 \%$ between 26 and 32, 35.7\% between 33 and 40, and $9.2 \%$ over 40 years old. Their educational background is $6.1 \%$ only completed primary education, followed by secondary $(27.5 \%)$; university studies $(57.9 \%), 8.5 \%$ have finished a post-graduate qualification (Master's Degree or $\mathrm{PhD}$ degree). Finally, monthly income ranged from below 250 US with $26.6 \% ; 54.6 \%$ of which lay between 250 USD500 USD, $16.2 \%$ between $500-1000$ USD; and $2.6 \%$ over 1000 USD. $35.7 \%$ of respondents live in Hanoi; their figure of Ho Chi Minh and Danang cities are 39\% and 25.3\%.

\subsection{Measurements of Constructs}

Respondents were asked to indicate their agreement on a seven point Likert scale ( 1 for strongly disagree and 7 for strongly agree) with statements on 4 main constructs namely: (a) consumer ethnocentrism; (b) consumer animosity against China; (c) Chinese children's foods quality judgments; (d) consumer's Willingness to buy for Chinese children's foods. The order of the questions followed Klein's 2002 method. This was done to reduce bias that may occur in the evaluation of products quality and Willingness to buy questions on consumer ethnocentrism and animosity should be asked first.

Measure ethnocentrism, reference was made to research by Shimp and Sharma [26], Nijssen \& Douglas [22], Klein \& Ettenson [17], all of which coincide in their use of the "Consumer Ethnocentrism Tendencies Scale" (CET SCALE).. This scale consists of 17 items which were validated in several contexts such as the USA, France, Japan, Germany, and China. The interchangeability of the 
CETSCALE indicators allows researchers to employ fewer indicators to measure this variable [17]. For this study, the six-item version of the original scale was utilized to measure ethnocentrism.

Measure animosity, the animosity scale developed and validated by Klein $[16,18]$. Results from pretest questionnaires and interviews revealed different opinions among Vietnamese consumers with regarding to the war animosity constructs, but there are no significant differences in respect of general and economic animosity. For this study, the 9-item scale version of the original was utilized to measure animosity with war (4 items) and economic causes (5 items).

Measure product judgments, the effect of consumer animosity on product judgment is inconclusive. In Klein et al [18] original model, consumer animosity had no impact on product evaluations. Klein \& Ettenson [17] replicated this finding in their first study of Australian consumers' boycott of French products. Yet, in their second study, which was conducted a year later, they found that animosity toward France actually had a negative impact on Australian consumers' quality judgments of French products. In this case, we used six-item scale version of the original from Klein et al., [18] to measure the Chinese Children's foods product judgments ( $1=$ "strongly disagree," and $7=$ "strongly agree").
Measure willingness to buy, The items used to measure willingness to buy were formulated especially on the basis of works by Klein et al [18]. The 6 items scale version of the original from Klein et al [18] was used to measure the Chinese Children's foods willingness to buy. In addition, the final section of the questionnaire collected personal demographic and socio-economic information, using scales for age, income, profession, education and gender.

\section{Results}

\subsection{Assessing the Reliability and Validity of Measures}

The information from the questionnaire was analyzed using SPSS 21.0 statistical software package to enable preliminary univariant and bivariant analysis to be performed, which showed no significant anomalies. Exploratory factor analysis was then conducted to ensure the unidimensionality of the latent variable measurements, specifically principal factor analysis (varimax rotation) which resulted in the identification of factors. Following the suggestions of Anderson and Gerbing [1], prior to examining the structural models Confirmatory Factor Analysis (CFA) by AMOS software was used in order to test the discriminant and convergent validity of factors. Table below shows the results of this analysis.

Table 1. Exploratory factor analysis

\begin{tabular}{|c|c|c|c|c|}
\hline & $\begin{array}{c}\text { Consumer } \\
\text { ethnocentrism } \\
\text { EN1-EN6 }\end{array}$ & $\begin{array}{c}\text { Consumer animosity* } \\
\text { WAN1-WAN4 } \\
\text { EAN1-EAN5 }\end{array}$ & $\begin{array}{c}\text { Product } \\
\text { judgments** } \\
\text { PJ1-PJ6 }\end{array}$ & $\begin{array}{c}\text { Willingness to buy } \\
\text { WB1-WB6 }\end{array}$ \\
\hline Cronbach's $\alpha$ & 0.866 & $0.706 \& 0.872$ & 0.808 & 0.858 \\
\hline KMO & 0.85 & 0.841 & $=0.766$ & 0.838 \\
\hline Bartlett & $\mathrm{p}<0.05$ & $\mathrm{p}<0.05$ & $\mathrm{p}<0.05$ & $58.630 \%$ \\
\hline $\begin{array}{c}\text { EFA } \\
\text { explain }\end{array}$ & $60.181 \%$ & $36.22 \% \& 25.123 \%$ & $64.385 \%$ & 4.579 \\
\hline $\begin{array}{c}\text { CFA } \\
\text { Chi-square/Df }\end{array}$ & 4.214 & 3.898 & 5.117 & 0.05 \\
\hline CFA- GFI & 0.947 & 0.928 & 0.958 & 0.974 \\
\hline CFA- CFI & 0.989 & 0.977 & 0.075 & 0.988 \\
\hline CFA- RMSEA & 0.075 & 0.059 & 0.065 \\
\hline
\end{tabular}

* Consumer animosity is measured by two subcomponents: The first subcomponent, the war animosity (WAN) through 4 questions (WAN1-WAN4). The second subcomponent, Economic animosity (EAN) through 5 questions (EAN1-EAN5)

** The 6 product judgments variables (PJ1-PJ6) were tested the reliability with Cronbach's $\alpha$ was 0.626 ; so it confirms that scale was not good. Corrected Item-Total Correlation of PJ1 and PJ4 were 0.158 and 0,257 respectively (A rule-of-thumb is that these values should be at least 0.40 ). After two times of elimination of PJ1 (Children's foods made in China are carefully produced and have fine workmanship) and PJ4 (Children's foods made in China usually show a very clever use of color and design), the reliability with Cronbach's $\alpha$ is 0.808 ; so it confirms that scale is good. 
According to Hair et al [11] with a large enough sample size, fit indices show the model fit with the following values: Chi-square/Df $<5$; GFI $>.90$, CFI $>.90$, RMSEA $<0.1$. In this model, the indices show that the model fits with the research data so well. Standardized regression weights $>0.5$; so it can be concluded that:

- Component of Consumer ethnocentrism factor achieves convergent validity.

- Correlation between WAN and EAN components is under 0.5 and $\mathrm{p}<0.05$. So it can be concluded that two components of consumer animosity achieve discriminant and convergent validity.

- Component of Consumer product judgments factor achieves convergent validity.

- Component of Consumer willingness to buy factor achieves convergent validity.

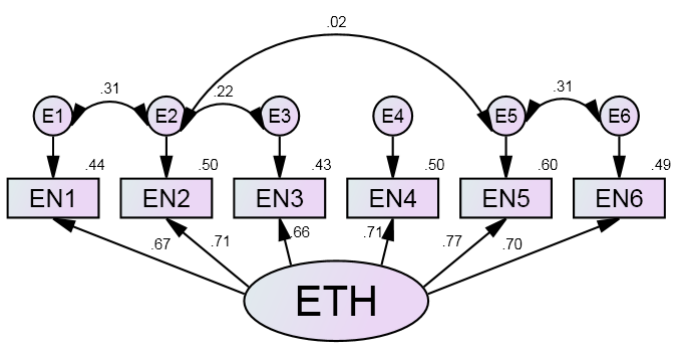

Figure 2. Consumer ethnocentrism-ETH (CFA standardized estimates)

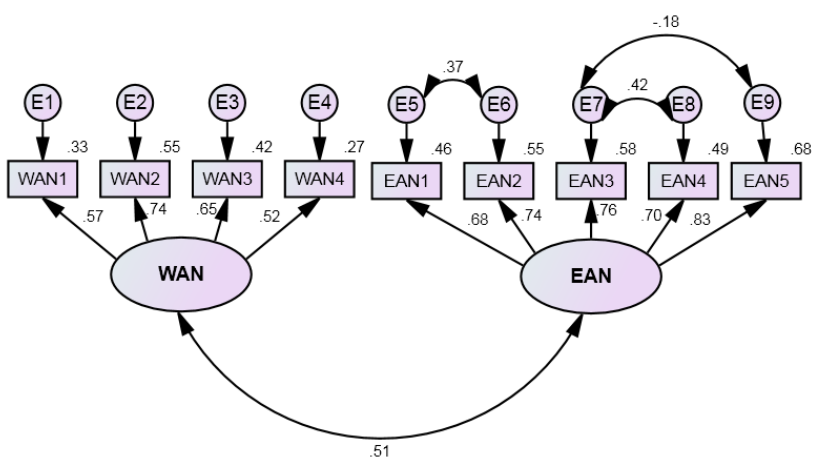

Figure 3. Consumer Animosity - (WAN - EAN) (CFA standardized estimates)

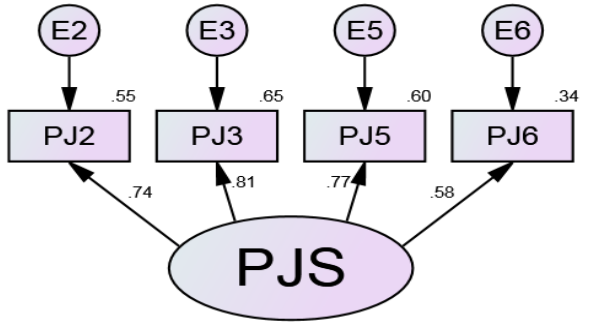

Figure 4. Product judgments-PJS (CFA standardized estimates)

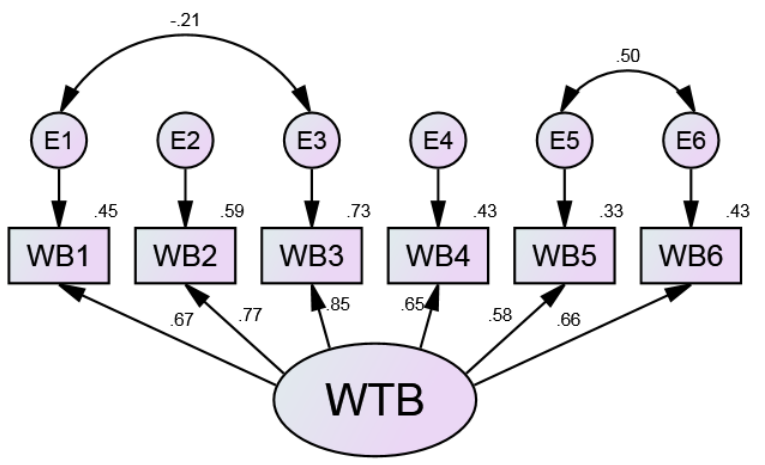

Figure 5. Willingness to buy - WTB (CFA standardized estimates)

In brief, both measurement models were theoretically and empirically sound. In the next section, we tested the full model. By doing this, we tested the effect of ethnocentrism, animosity product judgments on dependent factor and Product judgments' mediating role.

\subsection{Assessing the Model Fit with Structural Equations Modeling (SEM)}

In the full Model, The estimated results of structural model are shown in Figure 6 as following: Chi-square/Df $=4.07$; $\mathrm{GFI}=0.943 ; \mathrm{CFI}=0.923 ; \mathrm{RMSEA}=0.060$.

According to Hair et al, [11], there is no absolute value for the various fit indices suggest a good fit. The values associated with acceptable models vary from situation to situation and depend considerably on the sample size, number of measured variables, and the communalities of the factors. In this structural model, almost of fit indices are approached with good value. 


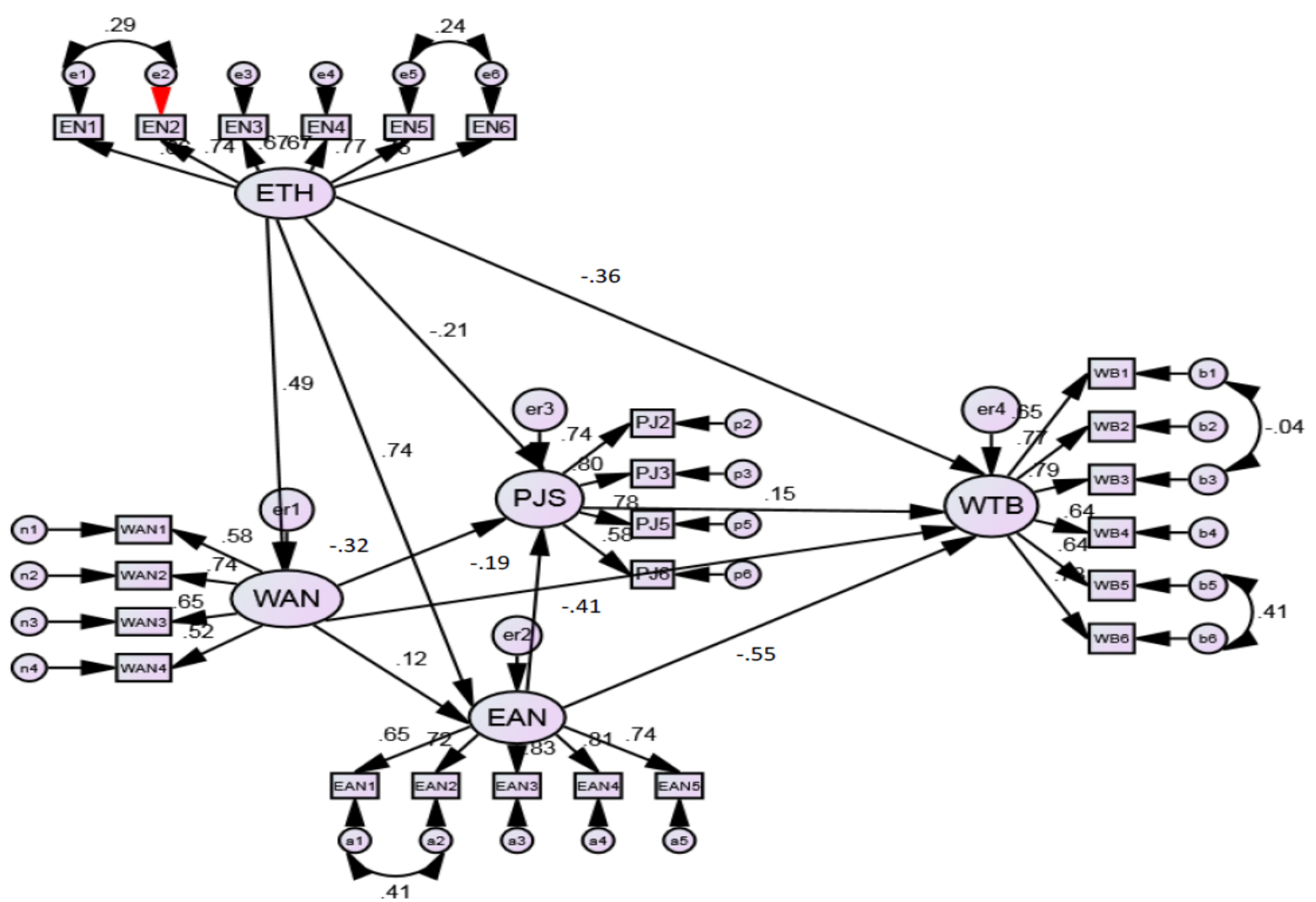

Figure 6. Structural Model

Table 2. Hypothesis results

\begin{tabular}{|c|c|c|c|c|}
\hline Hypotheses & Linkage & Estimate & P-value & Result \\
\hline $\mathrm{H} 1$ & $\mathrm{ETH} \rightarrow \mathrm{WTB}$ & -.36 & $* * *$ & Supported \\
\hline $\mathrm{H} 2 \mathrm{~A}$ & $\mathrm{WAN} \rightarrow \mathrm{WTB}$ & -.41 & $* * *$ & Supported \\
\hline $\mathrm{H} 2 \mathrm{~B}$ & $\mathrm{EAN} \rightarrow \mathrm{WTB}$ & -.55 & $* * *$ & Supported \\
\hline $\mathrm{H} 3 \mathrm{~A}$ & $\mathrm{ETH} \rightarrow \mathrm{WAN}$ & .49 & $* * *$ & Supported \\
\hline \multirow[t]{3}{*}{$\mathrm{H} 3 \mathrm{~B}$} & $\mathrm{ETH} \rightarrow \mathrm{EAN}$ & .75 & $* * *$ & Supported \\
\hline & $\mathrm{ETH} \rightarrow \mathrm{PJS}$ & -.21 & $* * *$ & Supported \\
\hline & $\mathrm{PJS} \rightarrow \mathrm{WTB}$ & .15 & .003 & Supported \\
\hline \multirow[t]{2}{*}{$\mathrm{H} 4 *$} & $\mathrm{ETH} \rightarrow \mathrm{PJS} \rightarrow$ WTB & -.0315 & & Supported \\
\hline & $\mathrm{WAN} \rightarrow \mathrm{PJS}$ & -.32 & $* * *$ & Supported \\
\hline \multirow[t]{2}{*}{ H5A* } & $\mathrm{WAN} \rightarrow \mathrm{PJS} \rightarrow$ WTB & -.048 & & Supported \\
\hline & $\mathrm{EAN} \rightarrow \mathrm{PJS}$ & -.19 & $* * *$ & Supported \\
\hline H5B* & $\mathrm{EAN} \rightarrow \mathrm{PJS} \rightarrow \mathrm{WTB}$ & -.029 & & Supported \\
\hline
\end{tabular}

*Based on the prior work of Stolzenberg for estimating indirect effects: $(-.0315=-.21 x .15),(-.048=-.32 x .15)(-.029=-.19 x .15)(27)$

The results showing that Consumer ethnocentrism has a significant and negative impact on Willingness to buy, standardized regression weights is -0.36 , so $\mathrm{H} 1$ is supported. Consumer war animosity has a significant and negative impact on Willingness to buy, standardized regression weights is -0.41 , so $\mathrm{H} 2 \mathrm{~A}$ is supported. Consumer economic animosity has a significant and negative impact on Willingness to buy, standardized regression weights is- 0.55 , so $\mathrm{H} 2 \mathrm{~B}$ is supported. Consumer ethnocentrism positively influences to consumer war animosity, standardized regression weights is 0.49 , so $\mathrm{H} 3 \mathrm{~A}$ is supported. Consumer ethnocentrism positively influences to consumer economic animosity, standardized regression weights is 0.75 , so $\mathrm{H} 3 \mathrm{~B}$ is supported. Product judgments mediate the relationship between consumer ethnocentrism and Willingness to buy, indirect effects of standardized regression weights is -0.0315 , so H4 is supported with marginal efficiency. Product judgments mediate the relationship between consumer war animosity and Willingness to buy, indirect effects of standardized regression weights is -0.048 , so $\mathrm{H} 5 \mathrm{~A}$ is 
supported with marginal efficiency. Product judgments mediate the relationship between consumer economic animosity and Willingness to buy, indirect effects of standardized regression weights is -0.029 , so $\mathrm{H} 5 \mathrm{~B}$ is supported with marginal efficiency.

In This study, we found that animosity has been perceived by Vietnamese consumers as prejudice and discrimination Chinese products. Ethnocentrism, on the other hand, represents perceptional enhancement and it increases the animosity. This suggests that consumer ethnocentrism not only serves as moral beliefs to purchase domestic products, but can also be regarded as the sensitivity of perceived threat from China. Product judgments were found to be a marginal mediator of consumer ethnocentrism and of consumer animosity (war and economic animosity) towards consumers' willingness to purchase Chinese children's foods. This finding is consistent with previous findings of Nijssen and Douglas [22]. We can see the fact that consumer ethnocentrism is able to further strengthen the significant and positive effect of consumer animosity (war and economic animosity) on the reluctance of Vietnamese consumers to purchase Chinese products. The research exhibits the fact that consumers who hold strong animosity towards a specific country are more likely to be influenced by negative evaluation of foreign products than those who do not hold such attitudes (standardized regression weight is -0.32 for WAN $\rightarrow$ PJS and -0.19 for EAN $\rightarrow$ PJS). Thus, the effect of product quality judgments is mediating the relationships between consumer animosity and willingness to purchase as well as between consumer ethnocentrism and willingness to purchase (standardized regression weight is -0.21 for $\mathrm{ETH} \rightarrow \mathrm{PJS})$.

\section{Discussion}

\subsection{Managerial Implications}

This study holds several implications for marketing practice. One of our findings provides additional support to the argument that companies from specific countries that try to expand in formerly "enemy "countries need to take into consideration not only the ethnocentric feelings, but, in addition, the level of consumer animosity that may be prevailing toward products originating in countries perceived by local consumers as "enemy" countries. Furthermore, before international marketing managers take any final decisions about the most appropriate country of origin, they should investigate the personal characteristics of the target consumer to verify whether they belong to the group of characteristics that are positively related to consumer animosity. Ignoring, though, such animosity conditions is the worst choice for international marketing managers, since it could cost their firm a loss of sales and profits.

Finally, our finding that Vietnamese consumers are very sensitive with products from China especially children's foods and they are willing to pay a premium to buy local instead of Chinese products, should be taken seriously into consideration by Chinese marketers when they take decisions concerning the pricing of products to be exported into Vietnam market. If Chinese food for children brand want to sell in Vietnamese market must have effective strategy to convince customer that their product is must better than other similar price product together with build brand reputation. To do that, Chinese foods for children brand should prove that their quality is good and valuable for its price with high assurance and also make customer believe that is true. All the marketing policies (4Ps) and marketing program and campaign must be well designed and carried out under the strategy direction.

\subsection{Limitations and Future Research}

There are several limitations to this study, as well as opportunities for future research. Generalization of the conclusions drawn from this work is restricted by the small sample size that is limited to a single geographic region. Moreover, the study only examines willingness to buy towards a specific product. Besides, it is a cross-sectional study; it would be interesting to design a longitudinal study that tracks survey participants over time to determine how relationships between variables change. A further limitation derives from product selected for the study: The Children's food product is a sensitive health sector where consumer's choice progressively depends on many psychology factors. An additional limitation comes from using the variable 'Willingness to buy' to measure the real purchase behavior, because consumer intentions do not include certain perceptions that the consumer only has when purchasing. Interestingly, it is important to note that consumers were not willing to state and openly admit their level of ethnocentrism and animosity because it represents a socially undesirable concept.

There are a number of future lines of research to emerge from this study that might enrich the limited research that exists on this topic. It would be interesting to test the proposed model in other cultural contexts (for more than one type of products and in more than one country), in order to compare results. Moreover, it could be useful to include other antecedents for ethnocentrism and animosity in the model, such as patriotism and purchase experience with the products being evaluated and to consider other quality signals and factors that influence consumer evaluations such as advertising and perceived value. Finally, a future study might test the mediating effects of some consumer personal characteristics and socio-economic variables on the proposed model.

\section{Appendix}

\section{Study Measures}

Consumer ethnocentrism (adapted from Klein et al., 1998)

1. Vietnamese products, first, last, and foremost. 
2. Purchasing foreign-made products is un-Vietnamese.

3. It is not right to purchase foreign products, because it puts Vietnamese out of jobs.

4. We should purchase products manufactured in Vietnam instead of letting other countries get rich off of us.

5. We should buy from foreign countries only those products that we cannot obtain within our own country.

6. Vietnamese consumers who purchase products made in other countries are responsible for putting their fellow Vietnamese out of work.

Animosity (adapted from Klein et al., 1998)

\section{War animosity}

1. I feel angry toward the Chinese.

2. I will never forgive China for what it has done to Vietnam in the past.

3. China should pay for what it has done to Vietnam in the past.

4. I dislike the Chinese.

\section{Economic animosity}

1. China is not a reliable trading partner.

2. China wants to gain economic power over Vietnam.

3. China is taking advantage of Vietnam.

4. China has too much economic influence in Vietnam.

5. The Chinese are doing business unfairly with Vietnam.

Product judgments (adapted from Klein et al., 1998)

1. Children's foods made in China are carefully produced and have fine workmanship. (Eliminated)

2. Children's foods made in China are generally of a lower quality than similar products available from other countries. (R)

3. Children's foods made in China show a very high degree of healthful and safe advancement.

4. Children's foods made in China usually show a very clever use of color and design. (Eliminated)

5. Children's foods made in China are usually quite reliable and suitable.

6. Children's foods made in China are usually a good value for the money.

Willingness to buy (adapted from Klein et al., 1998)

1. I would feel guilty if I bought a Chinese product.

2. I would never buy Children's foods made in China.

3. Whenever possible, I avoid buying Children's foods made in China.

4. Whenever available, I would prefer to buy Children's foods made in China.(R)

5. I do not like the idea of using Children's foods made in China.

6. If two products were equal in quality, but one was from China anode was from Vietnam, I would pay $10 \%$ more for the product from Vietnam.
$(\mathrm{R})=($ reverse-scored $)$

Correlation matrix between the latent variables

\begin{tabular}{|c|c|c|c|c|c|c|}
\hline & & ETH & EAN & WAN & PJS & WTB \\
\hline ETH & $\begin{array}{c}\text { Pearson } \\
\text { Correlation }\end{array}$ & 1 & & & & \\
\hline EAN & $\begin{array}{c}\text { Pearson } \\
\text { Correlation }\end{array}$ & $.457^{*}$ & 1 & & & \\
\hline WAN & $\begin{array}{c}\text { Pearson } \\
\text { Correlation }\end{array}$ & $.25^{*}$ & .51 & 1 & & \\
\hline PJS & $\begin{array}{c}\text { Pearson } \\
\text { Correlation }\end{array}$ & $-.137 *$ & $-.356^{*}$ & $-.225 *$ & 1 & \\
\hline WTB & $\begin{array}{c}\text { Pearson } \\
\text { Correlation }\end{array}$ & $-.337^{*}$ & $-.553 *$ & $-.392 *$ & $.281 *$ & 1 \\
\hline
\end{tabular}

*. Correlation is significant at the 0.05 level (2-tailed).

\section{Acknowledgements}

This research is funded by Vietnam National Foundation for Science and Technology Development (NAFOSTED) under grant number II4.3-2011.16

\section{REFERENCES}

[1] Anderson, J. C., \& Gerbing, D. W. (1988). Structural Equation Modeling in Practice: A Review and Recommended Two-Step Approac, Psychological Bulletin

[2] Ang S.H., Jung K., Kau A.K., Leong S.M., Pornpitakpan C., Tan S.J. (2004): "Animosity towards economic giants: what the little guys think", Journal of Consumer Marketing, 21:2/3, pp. 190-207.

[3] Averill J.R., 1982. Anger and Aggression: An Essay on Emotions. Springer, New York

[4] Balabanis, G., Mueller, R., Melewar, T.C. (2002): "The values' lenses of country of origin images", International Marketing Review, 19:6, pp. 582-610.

[5] Buss A.H., 1971. Aggression plays. In: Singer J.L. (Ed.). The Control of Aggression and Violence. Academic Press, New York

[6] Chandon, P., Morwitz, V.G., Reinartz, W.J. (2005): "Do Intentions Really Predict Behaviour? Self-Generated Validity Effects in Survey Research", Journal of Marketing, 69: 2, pp. $1-14$.

[7] Cordell, V.V. (1992): "Effects of Consumer Preferences for Foreign Sourced Products", Journal of International Business Studies, 23:2, pp. 251-269

[8] Ettenson, R. and Klein J.G. (2005): "The fallout from French nuclear testing in the South Pacific", International Marketing Review, 22:2, pp. 199-224.

[9] Fernández, P; Del Río, M.L. and Bande, B. (2003): "Etnocentrismo y animosidad del consumidor: antecedentes y consecuencias", Revista Europea de Dirección y Economía de la Empresa, 12:1, pp.177-188. 
[10] Granzin, K.L. and Painter, J.J. (2001): "Motivational influences on buy domestic purchasing: Marketing management implications from a Study of Two Nations", Journal of International Marketing, 9:2, pp. 73-94.

[11] Hair, B., Babin, Anderson, Tatha,. (2006): "Multivariate Data Analysis", Pearson Prentice Hall.

[12] Hamin, and Elliot, G. (2006). A Less-Developed Country Perspective of Consumer Ethnocentrism and "Country of Origin' Effects: Indonesian Evidence, Asia Pacific Journal of Marketing and Logistics, 18 (2), pp. 79-92

[13] Hamzaoui, L. and Merunka, D. (2006): "The impact of country of design and country of manufacture on consumer perceptions of bi-national products quality: an empirical model based on the concept of fit", The Journal of Consumer Marketing, 23:3, pp. 145-155

[14] Jung K., Ang S.H., Leong S.M., Tan S.J., Pompitakpan C., Kau A.K. (2002), A typology of animosity and its cross nation validation, Journal of Cross Cultural Psychology, 33 (6), pp. 529-39

[15] Kaynak, E. and Kara, A. (2002): "Consumer perceptions of foreign products: An analysis of product-country images and ethnocentrism", European Journal of Marketing, 36:7/8, pp. 928-949.

[16] Klein, J.G. (2002): "Us versus them, or us versus everyone? Delineating consumer aversion to foreign goods", Journal of International Business Studies, 33:2, pp. 345-363

[17] Klein, J.G. and Ettenson R. (1999): "Consumer animosity and consumer ethnocentrism: An analysis of unique antecedent", Journal of International Consumer Marketing, 11:4, pp. 5-24.

[18] Klein, J.G., Ettenson, R., Morris, M. (1998): "The animosity model of foreign product purchase: an empirical test in the People's Republic of China", Journal of Marketing, 62:1, pp. 89-100.

[19] LeVine, R.A. and Campbell, D.T. (1972), Ethnocentrism: Theories of Conflict, Ethnic Attitudes, and Group Behaviour, New York: John Wiley \& Sons Inc
[20] Netemeyer, R. G., Durvasula, S., Lichtenstein, D. R. (1991): "A cross-national assessment of the reliability and validity of the CETSCALE". Journal of Marketing Research, 28:3, 320-327.

[21] Newberry, C.R., Klemz, B.R., Boshoff, C. (2003): "Managerial implications of predicting purchase behavior from purchase intentions: a retail patronage case study", The Journal of Services Marketing, 17:6/7, pp. 609-618.

[22] Nijssen, E.J. and Douglas S.P., (2004): "Examining the animosity model in a country with a high level of foreign trade", International Journal of Research in Marketing, 21:1, pp. 23-38.

[23] Ouellet, J.F. (2007): "Consumer Racism and Its Effects on Domestic Cross-Ethnic Product Purchase: An Empirical Test in the United States, Canada, and France", Journal of Marketing, 71:1, pp. 113-128.

[24] Rose, M., Rose, G. M. and Shoham, A. (2009), The impact of consumer animosity on attitudes towards foreign goods: a study of Jewish and Arab Israelis, Journal of Consumer Marketing, 26 (5): 330-339.

[25] Sharma, S., Shimp T., Shin J. (1995): "Consumer Ethnocentrism: A test of antecedents and moderators", Journal of the Academy of Marketing Science, 23:1, pp 26-37.

[26] Shimp, T. A. and Sharma, S. (1987): "Consumer Ethnocentrism: Construction and Validation of the CETSCALE", Journal of Marketing Research, 24:3 pp. 280-289

[27] Stolzenberg, R. M. and Land, K. C. 1983." Handbook of survey research" Edited by: Rossi, P., Wright, J. and Anderson, A. 613-675. New York: Academic Press

[28] Suh, T. and Kwon, I.G. (2002): "Globalization and reluctant buyers", International Marketing Review, 19:6, pp. 663-680.

[29] Sumner, G. W. (1906): Folkways: The Sociological Importance of Usages, Manners, Customs, Mores, and Morals, Ginn and Co., Nueva York, NY 